Marcin Pytel (Lublin)

\title{
Uwagi nad przekazem dokumentu fundacyjnego klasztoru cystersów w Lądzie
}

Rzekomy dokument fundacyjny klasztoru cystersów w Lądzie zachował się w dwóch wersjach: dłuższej, czyli egzemplarzu kolońskim, oraz krótszej, czyli egzemplarzu włocławskim. Egzemplarz koloński dotrwał do naszych czasów w rzekomym oryginale, który obecnie przechowywany jest w archiwum miasta Kolonii. Do dziś przy dokumencie kolońskim znajdują się dwie sfałszowane pieczęcie Mieszka III. Dokument koloński był czterokrotnie transumowany: w $1261 \mathrm{r}$. został potwierdzony przez Bolesława Pobożnego ${ }^{1}$, w 1280 r. przez Przemysła $\mathrm{II}^{2}$, następnie w 1324 r. Władysław Łokietek konfirmował transumpt Bolesława Pobożnego ${ }^{3}$, by w dwa lata później potwierdzić rzekomy oryginał Mieszka III ${ }^{4}$. Transumpt ten z kolei został potwierdzony notarialnie w $1375 \mathrm{r}$. przez notariusza publicznego Budzisława, syna Pawła ze Strachocic ${ }^{5}$. Na dorsie tego dokumentu widnieje odręcznie wykonany w XV w. napis: de fundacione cenobii. W XV-wiecznym, według Tomasza Jurka podstawowym, kopiariuszu lędzkim tekst dokumentu wpisano pod nagłówkiem: Privilegium patronale fundacionis domus Landensis ${ }^{6}$. Natomiast egzemplarz włocławski znany jest jedynie z czterech nowożytnych

${ }^{1}$ Kodeks Dyplomatyczny Wielkopolski, t. I, wyd. I. Zakrzewski, Poznań 1877-1881, nr 393 [dalej: KDW].

${ }^{2}$ KDW, t. VI, wyd. A. Gąsiorowski i H. Kowalewicz, Warszawa-Poznań 1982, nr 27.

${ }^{3} \mathrm{KDW}, \mathrm{t}$. II, nr 1042.

${ }^{4}$ Ibidem, nr 1072.

5 J. Lelewel, Początkowe prawodawstwo polskie cywilne i kryminalne do czasów jagiellońskich, Warszawa 1828, s. 166.

${ }^{6}$ Cyt. za: T. Jurek, Dokumenty fundacyjne opactwa w Ladzie, „Roczniki Historyczne” 2000, t. 66, s. 8,47 . 
kopii: dwóch kopiariuszy klasztornych XVII- i XVIII-wiecznych oraz z dwóch odpisów?

Oba egzemplarze rzekomego dokumentu fundacyjnego mówią o sprowadzeniu konwentu z Altenbergu przez Mieszka III i osadzeniu mnichów w Lądzie. Wymieniają też uposażenie klasztoru w dwóch grupach, złożone ze wsi i ludzi, przy czym obie grupy przedzielone są tzw. instruktarzem, czyli wykazem obowiązków i powinności mieszkańców pierwszej grupy. Krótsza wersja jednak opuszcza cały fragment tekstu zawarty między wykazem wsi drugiej grupy a korroboracją dłuższej wersji dokumentu, tj. obowiązki mieszkańców klasztoru ciągnienia sieci poniżej Sieradza i Włocławka oraz noszenia, pieszo czy konno, listów klasztornych per totam Poloniam, uprawnienia do polowań i rybołówstwa, wszędzie tam, gdzie polują i łowią ludzie książęcy, nadania trzech targów z karczmami oraz pełny immunitet sądowy i ekonomiczny. Egzemplarz włocławski pomija również ostatnią z wymienionych wsi klasztornych drugiej grupy, Świniarzewo, a w wykazie obowiązków i powinności mieszkańców pierwszej grupy klasztoru liczbę dostarczanych wozów siana i drewna pomniejsza do dwóch, podczas gdy w egzemplarzu kolońskim mowa jest o trzech. Oba egzemplarze różnią się też pod względem ortografii.

Dłuższą wersję rzekomego dokumentu fundacyjnego po raz pierwszy opublikował Joachim Lelewel z instrumentu notarialnego z $1375 \mathrm{r}^{8}{ }^{8}$ Kolejna edycja owego dokumentu nastąpiła z chwilą opublikowania Kodeksu Dyplomatycznego Polski. Tym razem jednak oparto ją na transumpcie Władysława Łokietka z 1324 r., potwierdzającego wprawdzie transumpt Bolesława Pobożnego z 1261 r., ale zawierającego jedynie tekst rzekomego przywileju Mieszkowego w dłuższej wersji ${ }^{9}$. Krótszą wersję dokumentu opublikował dopiero płk Ignacy Zakrzewski w Kodeksie Dyplomatycznym Wielkopolski z XVIII-wiecznego kopiariusza klasztornego przechowywanego w archiwum miasta Poznania ${ }^{10}$, dlatego później w literaturze określano go mianem egzemplarza poznańskiego. Kolejnych edycji doczekały się rzekome dokumenty fundacyjne klasztoru w Lądzie dopiero w ostatnim dziesięcioleciu. Pomimo że Henryk Waraczewski opublikował dłuższą wersję rzekomego dokumentu fundacyjnego, posługując się jego podobizną ${ }^{11}$, wszystkie edycje obu wersji rzekomego dokumentu fundacyjnego nie grzeszyły poprawnością, toteż ostatni monografista początków klasztoru w Lądzie opublikował ponownie zarówno

7 S. Damalewicz, Series Archiepiscoporum Gnesnensium, Varsoviae 1649, s. 91-92; K. Jarmundowicz, Fundacja kościoła i klasztoru lendzkiego świętego zakonu cystercjenskiego sześcia wiekami trwałości swojej stwierdzona..., Poznań 1745, k. I 2.

8 J. Lelewel, Poczatkowe prawodawstwo..., s. 166-169.

9 Codex Diplomaticus Poloniae, t. I, wyd. L. Ryszczewski, A. Muczkowski, A. Helcel, Varsoviae 1847, $\mathrm{nr} 1$ [dalej: CDP].

${ }^{10} \mathrm{KDW}$, t. I, nr 10.

11 H. Waraczewski, Proces fundacyjny klasztoru w Lądzie nad Warta, „Nasza Przeszłość” 1994, t. 83 , s. $163-167$. 
dłuższą jego wersję z mikrofilmu przygotowanego w archiwum miasta Kolonii, jak i krótszą - z nieznanej dotąd, a odnalezionej przez niego w Archiwum Diecezjalnym Włocławka kopii ${ }^{12}$, którą za T. Jurkiem będę nazywał egzemplarzem włocławskim.

Studia krytyczne nad obiema wersjami rzekomego dokumentu fundacyjnego rozpoczął Antoni Helcel, kwestionując autentyczność ${ }^{13}$ dłuższej wersji na podstawie użytego w tekście dokumentu zaimka nos, zwrotu nobiles, zbyt obszernej klauzuli immunitetowej oraz faktu, iż mnisi lędzcy w czasie procesu z mieszkańcami Dolan przedłożyli najpierw Władysławowi Łokietkowi do transumowania potwierdzenie Bolesława Pobożnego, by dopiero w dwa lata później transumować sam akt Mieszkowy, którego data potwierdzenia wyznaczała jednocześnie czas sfałszowania rzekomego dokumentu fundacyjnego ${ }^{14}$. Franciszek Piekosiński, recenzując Kodeks Dyplomatyczny Wielkopolski ${ }^{15}$, omówił krótszą wersję rzekomego dokumentu fundacyjnego klasztoru w Lądzie i uznał ją z miejsca za falsyfikat sporządzony w latach 20. XIV w. na potrzeby procesów klasztoru z mieszkańcami Dolan. Przeciw autentyczności tego dokumentu miała świadczyć według niego lista świadków niezgodna z rzekomą datą wystawienia dokumentu oraz błędnie oddane elementy datacyjne: indykcja w 1145 r. przypadała IX, nie VIII, a epakta XXV, nie VI, jak figuruje na dokumencie. Argumenty F. Piekosińskiego podtrzymał Wojciech Kętrzyński, ale już w odniesieniu do dłuższej wersji dokumentu ${ }^{16}$, którego czas fałszerstwa wyznaczał na przełom lat 70. i 80. XIII w., czyli czas potwierdzenia dokumentu przez Przemysła II. W. Kętrzyński ustalił też najwcześniejsze dzieje klasztoru w Lądzie i dwóch faz jego fundacji oraz odniósł z listy świadków rzekomego dokumentu fundacyjnego, którą traktował jako luźny zlepek, arcybiskupa Piotra i biskupa Mrokotę, utożsamiając go z występującym w egzemplarzu kolońskim biskupem poznańskim o imieniu zapisanym jako Marchodius, do rzeczywistych świadków, ale drugiej, z lat 90., fundacji lędzkiej ${ }^{17}$. W. Kętrzyński zauważył też, że przy dokumencie kolońskim wiszą dwie autentyczne pieczęcie Mieszka III.

12 T. Jurek, Dokumenty fundacyjne..., s. 46-48. Badacz ten opublikował ponownie również inne dokumenty lędzkie, falsyfikat rzekomo z 1181 r. oraz transumpt rzekomego dokumentu fundacyjnego Bolesława Pobożnego z $1261 \mathrm{r}$.

${ }_{13}$ Zob. jego uwagi do edycji w CDP, t. I, nr 1 .

${ }^{14}$ Dwaj wydawcy, zarówno dłuższej, jak i krótszej wersji rzekomego dokumentu fundacyjnego klasztoru w Lądzie, J. Lelewel i I. Zakrzewski, przyjmowali autentyczność opublikowanych przez siebie wersji. Również A. Małecki przyjmował ten pogląd (Klasztory i zakony w Polsce w obrębie wieków średnich, „Przewodnik Naukowy i Literacki” 1875, t. 3, s. 591), choć w późniejszej pracy uznał obie wersje rzekomego dokumentu fundacyjnego za sfałszowane ( $W$ kwestii fatszerstwa dokumentów, „Kwartalnik Historyczny”, t. 18, 1904, s. 472).

15 „Przegląd Krytyczny” 1877, t. 12, s. 448.

16 W. Kętrzyński, Studia nad dokumentami XII w., „Rozprawy Akademii Umiejętności. Wydział Historyczno-Filozoficzny" 1891, t. 26, s. 83-85.

${ }^{17}$ Ibidem. 
Dotychczasowy stan badań podsumowała Zofia Kozłowska-Budkowa, ustalając dokładną datę fałszerstwa dłuższej wersji dokumentu, rozpoznawszy jeden charakter pisma, jakim był spisany zarówno omawiany akt, jak i jego transumpt z 1261 r., którego autentyczności broniła. Powątpiewając przy tym w przekaz krótszej wersji omawianego dokumentu, wyraziła przypuszczenie, iż jest ona wcześniejszą wersją falsyfikatu znanego z rzekomego oryginału, wyznaczając czas jego powstania przed pierwszą połową XIII w. Badaczka była też sceptyczna co do możliwości ostatecznego rozstrzygnięcia, czy istniał autentyczny dokument Mieszka III dla Lądu, czy nie ${ }^{18}$.

W powojennej historiografii ${ }^{19}$ rzekomym dokumentom klasztoru cystersów w Lądzie nie poświęcano zbyt wiele uwagi. Stanisław Trawkowski, szczegółowo analizując obowiązki i powinności mieszkańców wsi cystersów lędzkich i wydzielając z nich elementy archaiczne, przyczynił się też w pewnym stopniu do krytyki ich autentyczności ${ }^{20}$. Warto odnotować, że pracę tę pomijali wszyscy późniejsi badacze historii klasztoru w Lądzie. Zresztą kolejne dwie prace też niewiele wniosły: Andrzej Marek Wyrwa ${ }^{21}$ i Henryk Waraczewskii ${ }^{22}$ poza zreferowaniem stanu badań nie dodali nic od siebie do krytyki autentyczności rzekomo najstarszych dokumentów lędzkich. Dopiero publikacja T. Jurka ${ }^{23}$ przyniosła kilka nowych hipotez. Swoich rozważań nad najwcześniejszymi dokumentami klasztoru w Lądzie nie oparł on bowiem jedynie na znanych dotąd przekazach, lecz poszerzył bazę źródłową o kolejne odpisy krótszej wersji rzekomego dokumentu fundacyjnego, który uznał za antydatowany autentyk Mieszka III z połowy lat 90. XII w. Przyjął też istnienie trzeciej wersji dokumentu fundacyjnego, którą mnisi lędzcy mieli przedłożyć do konfirmacji Bolesławowi Pobożnemu w 1261 r., natomiast powstanie trzeciej wersji dokumentu fundacyjnego, czyli egzemplarza kolońskiego, wiązał z konfirmacją Przemysła II z 1280 r. ${ }^{24}$ T. Jurek uznał heterogeniczność elementów datacyjnych, które miały być

${ }^{18}$ Z. Kozłowska-Budkowa, Repertorium polskich dokumentów doby piastowskiej, z. 1: Do końca XII w., Kraków 1937, s. 43-45.

19 Należy zaznaczyć, że przedwojenne opracowanie dziejów klasztoru w Lądzie opiera się wyłącznie na wcześniejszych ustaleniach M. Kamińskiego, Dawne opactwo zakonu cysterskiego w Lqdzie nad Warta, Warszawa 1936. Podobnie dwaj monografiści immunitetu w Polsce średniowiecznej nie wnoszą nic nowego do krytyki autentyczności rzekomo najstarszych dokumentów lędzkich. Por. K. Kaczmarczyk, Immunitet sądowy i jurysdykcja poimmunitetowa $w$ dobrach kościoła $w$ Polsce do końca XIV w., Poznań 1936, s. 245-247; J. Matuszewski, Immunitet ekonomiczny w dobrach kościoła w Polsce do r. 1381, Poznań 1936, s. 360.

${ }^{20}$ S. Trawkowski, Gospodarka wielkiej własności cysterskiej na Dolnym Ślasku w XIII w., Warszawa 1959, s. 111-113, 132-140.

${ }^{21}$ A.M. Wyrwa, Procesy fundacyjne klasztorów cysterskich linii altenberskiej, Poznań 1995, s. 83-86.

${ }^{22}$ H. Waraczewski, Proces fundacyjny..., s. 152-157.

${ }^{23}$ T. Jurek, Dokumenty fundacyjne...

${ }^{24} \mathrm{KDW}, \mathrm{t}$. VI, nr 27. 
oddane w stylu Zwiastowania, w odmianie florenckiej. Przyimek nos wedle niego nie może przemawiać przeciw autentyczności dokumentu, ponieważ występuje na autentycznym dokumencie Mieszka III dla klasztoru w Lubiążu. Listę świadków badacz uznał za autentyczną dla lat 90 . XII w., a egzemplarz włocławski dokumentu za autentyk oparty na autentycznej zapisce, przerobiony w połowie lat 90 . XII w., czyli w czasach drugiej fundacji klasztoru ${ }^{25}$. Tezy te podważył Tomasz Ginter. Wedle niego elementy datacyjne są niespójne, nieodpowiadające dacie dziennej wystawionego dokumentu. Również na podstawie analizy formularza dokumentu wysnuł wniosek, że są one nieobecne na dokumentach z XII w. Podobnie rozważania nad stroną sfragistyczną dokumentu - podwójne opieczętowanie dłuższej wersji dwiema pieczęciami Mieszka III - doprowadziły obu autorów do odmiennych wniosków ${ }^{26}$.

Własną analizę wzajemnej relacji obu wersji rzekomego dokumentu fundacyjnego rozpocznę od porównania pisowni nazw osobowych i miejscowych obu wersji ${ }^{27}$, przy czym będę opierać się na dostępnych mi jedynie opublikowanych przekazach obu wersji rzekomego dokumentu fundacyjnego.

Uwagę skupię najpierw na poszczególnych lekcjach imion, a przekaz obu kopiariuszy lędzkich: krótszej wersji dokumentu i egzemplarza kolońskiego będę traktować osobno. Poniżej zestawiam wszystkie lekcje, którymi dysponuję.

Tabela 1. Wykaz nazw osobowych dokumentu fundacyjnego

\begin{tabular}{|l|l|l|}
\hline \multicolumn{1}{|c|}{ Kopiariusz włocławski } & \multicolumn{1}{|c|}{ Kopiariusz poznański } & \multicolumn{1}{|c|}{ Egzemplarz koloński } \\
\hline Miesco dux Poloniae & Mescho dux Poloniae & Mesico dux Polonie \\
Petro archiepiscopo & Petro archiepiscopo & Petro archiepiscopo \\
s.Gnesnensis ecclesiae & s.Gnesnensis ecclesiae & sancte Gnezn(ensis)ecclesie \\
Martino episcopo & Marlino episcopo & Marchodio episcopo \\
Posnaniensis ecclesiae & Posnaniensis ecclesie & Poznaniensis ecclesie \\
Stephano praeposito ibidem & Stephano praeposito ibidem & Stephano preposito ibidem \\
Citharaedo decano & Citharedo decano & Citharedo decano \\
Jarossio palatino & Jarossio palatino & Jarostio palatino \\
Boguphalo castelano & Boguphalo castelano & Boguphalo castellano \\
Gnesn(ensi) & Gnesn(ensi) & Gnezn(ensi) \\
Ulrico capellano & Ulrico capellano & Ylico capellano \\
\hline
\end{tabular}

${ }^{25}$ T. Jurek, Dokumenty fundacyjne..., s. 23-24, 27-28.

${ }^{26}$ T. Ginter, Działalność fundacyjna księcia Mieszka III Starego, Kraków 2008, s. 114-121. Podobną uwagę wyraził G. Labuda, uznając krótszą wersję dokumentu za falsyfikat. G. Labuda, Szkice historyczne X-XI wieku, Poznań 2004, s. 392, przyp. 103.

${ }^{27} \mathrm{Na}$ ortografię rzekomego dokumentu fundacyjnego klasztoru w Lądzie wprawdzie zwrócił już uwagę T. Jurek (Dokumenty fundacyjne..., s. 15), ale rozpatrywał on tylko zapis dłuższej wersji dokumentu, i to w porównaniu z jego transumptem z 1261 r. (ibidem, s. 28-29). 
Z zestawienia tego wynika, że tylko część imion oddana jest we wszystkich trzech przekazach w takiej samej formie - są to lekcje imion arcybiskupa Piotra, prepozyta poznańskiego Stefana, dziekana Ciecierada oraz kasztelana Boguchwała. Natomiast zapis pozostałych jest znacznie zróżnicowany. Charakterystyczne jest jednak to, że wszystkie lekcje imion przekazane przez egzemplarz koloński można odnaleźć w źródłach XII- i XIII-wiecznych. Na przykład formę zapisu imienia palatyna Jarosta odnajduję, oprócz rzekomo XII-wiecznych falsyfikatów lędzkich ${ }^{28}$, na wielu listach świadków XIII-wiecznych dyplomów z terenu Wielkopolski ${ }^{29}$. Podobnie rzecz się ma z zapisem imienia kapelana Ilika, które poza rzekomo XII-wiecznymi falsyfikatami lędzkimi spotykamy w niemal identycznej formie w nekrologu lubińskim ${ }^{30}$, w którym występuje jako Ilick, oraz w roczniku kapituły gnieźnieńskiej, gdzie zapis tego imienia brzmi Hilic ${ }^{31}$. Charakterystyczna jest również forma zapisu imienia księcia Mieszka III, którą w formie, jaką przekazał egzemplarz koloński (Mesico), odnajdujemy w licznych źródłach z XII w., by wymienić choćby zapisy w analogicznej formie z tzw. pateny kaliskiej ${ }^{32}$, autentycznego dyplomu Mieszka III dla klasztoru w Lubiążu z 1177 r. ${ }^{33}$ czy autentycznych pieczęci tego księcia ${ }^{34}$. Warto dodać, że w literaturze przedmiotu właśnie tę formę uznano za poprawną dla XII w. ${ }^{35}$

Zanim omówię ostatniego ze świadków rzekomego dokumentu fundacyjnego klasztoru w Lądzie, biskupa poznańskiego, którego zapis imienia na egzemplarzu kolońskim brzmi Marchodius, zauważę, że m.in. jego identyfikacja z Mrokotą posłużyła już W. Kętrzyńskiemu do datowania całej listy świadków na lata 90. XII w. ${ }^{36}$ Jednocześnie ks. Józef Nowacki i Andrzej Wędzki ${ }^{37}$, przyjmując lekcję

${ }^{28}$ Którego spotykamy na wszystkich rzekomo XII-wiecznych falsyfikatach lędzkich. Poprawną wersję zapisu jego imienia zawierają jednak tylko falsyfikaty rzekomo z 1174, 1173 i 1186 r., przy czym dwa ostatnie znane są z XIII-wiecznych rzekomych oryginałów. Pozostałe oddają je błędnie (jako Jarossius), a są to falsyfikaty rzekomo z 1181 i 1186 r., znane jednak tylko z XVIi XVIII-wiecznych kopii. Por. KDW, I, nr 20, 26, 27, 28; KDW, t. VI, nr 1.

${ }^{29}$ Por. formy zapisu imienia Jarost: KDW, I, nr 79, 119, 136, 147, 263, 283, 354, 357, 362, $363,368,404$.

${ }^{30}$ Roczniki wielkopolskie, wyd. B. Kürbis, MPH, s. n., t. VI, s. 10.

31 Ibidem, s. 3.

${ }^{32}$ M. Walicki (red.), Sztuka polska przedromańska i romańska do schyłku XIII wieku, t. II, Warszawa 1971, s. 725.

${ }^{33}$ Codex diplomaticus nec non epistolaris Silesiae, t. I, wyd. K. Maleczyński, Wrocław 1951, nr 59.

${ }^{34}$ Z. Piech, Ikonografia pieczęci Piastów, Kraków 1993, s. 204-205.

${ }^{35}$ Por. choćby W. Kętrzyński, Studia nad dokumentami..., s. 86.

${ }^{36}$ Ibidem, s. 84. Warto odnotować, że tę identyfikację zaakceptował też T. Jurek, Dokumenty fundacyjne..., s. 23-24.

37 J. Nowacki, Dzieje archidiecezji poznańskiej. Archidiecezja poznańska w granicach historycznych i jej ustrój, t. 2, Poznań 1964, s. 46-47; A. Wędzki, Rozwój osadnictwa i podziały terytorialne ziemi lądzkiej do końca XIV w., „Slavia Antiqua” 1966, t. 13, s. 45-46. 
krótszej wersji, i to w emendowanej już przez wydawcę formie: Martino ${ }^{38}$, przesuwali wbrew dawniejszej historiografii datę fundacji klasztoru w Lądzie na lata 40. XII w., a inicjatywę sprowadzenia mnichów do nowej wielkopolskiej placówki przypisali biskupowi poznańskiemu Marcinowi. Nietrudno jednak obalić ten pogląd. Większość świadków można bowiem zidentyfikować dla lat 90. XII w. i tym samym ${ }^{39}$ potwierdzić poprawność lekcji imienia biskupa oddanej w egzemplarzu kolońskim.

Zanim przystąpię do analizy nazw miejscowych obu wersji rzekomego dokumentu fundacyjnego klasztoru w Lądzie, odnotuję, że spośród nazw osobowych przekazanych przez obie wersje, to lekcje egzemplarza kolońskiego okazują się poprawne, podczas gdy zapis części imion świadków przekazanych w kopiariuszach nie odpowiada ortografii XII- i XIII-wiecznej. Dokonam zatem rozbioru nazw miejscowych obu przekazów, które poniżej zestawiam w dwóch grupach, w kolejności, w jakiej znamy je z rzekomego dokumentu fundacyjnego.

Tabela 2. Wykaz nazw miejscowych dokumentu fundacyjnego

\begin{tabular}{|l|l|l|}
\hline \multicolumn{1}{|c|}{ Kopiariusz włocławski } & \multicolumn{1}{|c|}{ Kopiariusz poznański } & \multicolumn{1}{c|}{ Egzemplarz koloński } \\
\hline I & Kossol & Koszcol \\
Dolan & Dolan & Dolan \\
Morscho & Morsko & Morscho \\
Cloba & Cloba & Cloba \\
Moszczewe & Moszewe & Gotschene \\
& II & \\
Szetlewo & Szetlewo & Szechovo cum cocis \\
Rzgowo cum sanctuariis & Rzgowo cum sanctu- & Irgouo cum sanctuariis \\
et stabulariis* & ariis et stabulariis & et stabulariis \\
Grabienice cum camerario & Grabienice cum camerario & Grabonovyz cum camerariis \\
Sławsko cum piscatoribus & Sławsko cum piscatoribus & Slausco cum piscatoribus \\
Wyramowo & Wyramowo & Wiramovo \\
Kwaskowo & Kwaskowo & Quascouo \\
Chorzen & Chorzen & Choren \\
Starałąka & Starałąka & Staralanca \\
- & - & Suinarouo \\
\hline
\end{tabular}

* W pierwotnym odpisie w kopiariuszu włocławskim oddano jako Rzgowo cum stabulario i dopiero później skolacjonowano. Por. T. Jurek, Dokumenty fundacyjne..., s. 9.

${ }^{38}$ Jak to wynika z najnowszej edycji rzekomego dokumentu fundacyjnego klasztoru w Lądzie. T. Jurek, Dokumenty fundacyjne..., s. 46-47.

${ }^{39}$ Por. również najnowsze badania nad listą świadków omawianego dokumentu u T. Jurka. Ibidem, s. 23-24. 
Już na pierwszy rzut oka widać, że przekazy nazw miejscowych obu kopiariuszy lędzkich należą do odrębnej tradycji tekstowej niż przekaz egzemplarza kolońskiego, przy czym przekaz obu kopiariuszy zawiera dwa błędy. Szetlewo otwierające wykaz drugiej grupy wsi klasztornych w kopiariuszach występuje bez wymienienia kuchar, początkowo ludności służebnej zamieszkującej Szetlewo ${ }^{40}$, a następnie osobnej wsi klasztornej, w której w XVI i XIX w. odnajdujemy kościół parafialny ${ }^{41}$. Podobnie rzecz się ma z zapisem kopiariuszy Grabienice cum camerario, podczas gdy wieś Komorniki znana jest jeszcze w XVI w. ${ }^{42}$ Należy podkreślić, że zarówno Szetlewo, jak i Grabienice należą do grupy wsi klasztornych nadanych wraz z ludnością służebną, układającej się w jeden klucz ${ }^{43}$.

Przyjmując zatem poprawność wykazu wsi klasztornych oddanego w egzemplarzu kolońskim, a zarazem jego usterki w obu przekazach egzemplarza włocławskiego, porównam ortografię nazw miejscowych obu przekazów. Zaznaczę tylko, że podobnie jak w przypadku nazw osobowych analizie poddaję tylko część z nich. Część bowiem posiada zbliżone bądź nawet te same lekcje. Chodzi tu przede wszystkim o Kościół, Dolany, Morsko, Kłobię, Wiramowo i Chorzeń, z których zresztą jedynie Kłobię i Chorzeń spotykamy w źródłach średniowiecznych poza rzekomym dokumentem fundacyjnym klasztoru w Lądzie oraz jego transumptami. Kłobia ma zawsze tę samą lekcję: Cloba ${ }^{44}$, a zapis Chorzenia spotykamy tylko raz - w dokumencie z 24 II 1364 r. widnieje Alberto de Chorzna ${ }^{45}$. Podejrzenia budzą jednak zapisy kopiariuszy Grabienic, Sławska, Kwaskowa i Starejłąki oddane w formie z pewnością już spolszczonej. Wprawdzie nazwa Grabienice występuje też w źródłach średniowiecznych w takiej samej lub zbliżonej formie do zapisu z kopiariuszy lędzkich ${ }^{46}$, jednak zapis Sławska spotykamy w XIII w. w formie oddanej w egzemplarzu kolońskim jako Slausco ${ }^{47}$. Jeśli zaś chodzi o Kwaskowo

${ }^{40}$ K. Buczek, Książęca ludność stużebna w polsce wczesnofeudalnej, Warszawa 1958, s. 5-9, $87-104$.

41 J. Łaski, Liber Beneficiorum archidyecezyi gnieźnieńskiej, t. I, Gniezno 1880-1881, s. 43, por. również hasła [w:] F. Sulimierski, B. Chlebowski, W. Walewski (red.), Słownik geograficzny Królestwa Polskiego i innych krajów stowiańskich, t. 11, Warszawa 1892, s. 910-911; oraz S. Kozierowski, Badanie nazw topograficznych na obszarze dawnej zachodniej i środkowej Wielkopolski, t. 2, Poznań 1922, s. 394-395.

${ }^{42}$ J. Łaski, Liber Beneficiorum..., t. I, s. 611-612.

${ }^{43}$ A.M. Wyrwa, Procesy fundacyjne..., s. 118-119 i zamieszczoną tam ryc. 25.

${ }^{44}$ KDW, t. I, nr 298, 604; t. II, nr 707, 1093, 1094, 1158.

${ }^{45} \mathrm{KDW}, \mathrm{t}$. III, nr 1515.

${ }^{46} \mathrm{~W}$ dokumentach z 26 IV 1283 r. spotykamy zapis Grabieniche (KDW, t. I, nr 522); z 23 IV 1375 r. występuje Janko heres de Grabienic, a następnie de Grabienicze oraz de Grabienice (KDW, t. III, 1721); natomiast z 20 XI 1394 r. Andree de Grabyenicze (KDW, t. III, 1954). W XVI i XIX w. odnajdujemy wieś Grabienice, co potwierdzają J. Łaski, Liber Beneficiorum..., t. I, s. 284-286; oraz F. Sulimierski, B. Chlebowski, W. Walewski (red.), Stownik geograficzny..., t. 2, s. 765-766.

${ }^{47} \mathrm{KDW}, \mathrm{t} . \mathrm{I}, \mathrm{nr} 415,673,678$. 
i Starąłąkę, to choć byśmy szukali w źródłach średniowiecznych i nowożytnych innych ich zapisów ${ }^{48}$ poza transumptami rzekomego dokumentu fundacyjnego klasztoru w Lądzie, w których to zawsze występują w formie zgodnej z zapisem egzemplarza kolońskiego ${ }^{49}$, to nie ulega wątpliwości, że lepsze, tzn. starsze ich lekcje przekazuje egzemplarz koloński. Znane są bowiem powszechnie trudności, jakie napotykali zagraniczni przybysze, oddając na piśmie polskie toponimy ${ }^{50}$. Z podobną sytuacją mamy do czynienia przy rozbiorze nazwy Szetlewa, które w egzemplarzu kolońskim oraz jego transumptach ${ }^{51}$ spotykamy w formie Szechovo, a w kopiariuszach lędzkich - w formie, w jakiej spotykamy ją na dyplomach późnośredniowiecznych bądź w zapisach nowożytnych ${ }^{52}$. Nie ma tu znaczenia, że zapis Szetlewa występuje jeszcze w formie znanej nam z kopiariuszy lędzkich na dokumencie rzekomo z 1242 r., który okazuje się falsyfikatem z początku lat 90. XIII w., bowiem dokument ten znamy jedynie z XVIII-wiecznego kopiariusza ${ }^{53}$. Niemniej decydujące znaczenie dla ustalenia chronologii nazw miejscowych obu przekazów rzekomego dokumentu fundacyjnego klasztoru w Lądzie ma analiza zapisów Rzgowa i Chocenia, dla których dysponujemy nieco szerszym materiałem porównawczym. Zapis Rzgowa poza egzemplarzem kolońskim i jego XIII-wiecznymi transumptami ${ }^{54}$ znajduje się bowiem na dokumencie Kazimierza Konradowica z 17 VII 1241 r. ${ }^{55}$ dla Lądu, gdzie wśród listy świadków figuruje Nycholaus de Yrgove. Jeszcze bardziej wymowne jest to, że omawiany dokument zredagowano nie w klasztorze lędzkim, lecz w kancelarii Kazimierza Konradowica ${ }^{56}$. Dysponując więc dwoma XIII-wiecznymi niezależnymi od siebie ${ }^{57}$ przekazami zapisu Rzgowa, można przyjąć jako starszą lekcję dla XIII w. oddaną na egzemplarzu kolońskim oraz na dokumencie Kazimierza Konradowica. Natomiast zapis Rzgowa przekazany w kopiariuszach klasztornych pojawia się najwcześniej w XIV w. ${ }^{58}$ i w takiej formie spotykamy go w XVI w. Pod koniec XIX w. oddawany jest już

${ }^{48}$ Kwaskowa i Starejłąki nie odnajdujemy już ani u Łaskiego, ani w Stowniku geograficznym...

${ }^{49} \mathrm{KDW}, \mathrm{t}$. I, II i VI.

${ }^{50}$ T. Jurek, Dokumenty fundacyjne..., s. 15.

${ }^{51} \mathrm{KDW}$, t. I, nr 393; KDW, t. VI, nr 27.

52 Ibidem.

${ }^{53}$ Por. edycję w KDW, t. I, nr 222.

${ }^{54}$ Jego zapis jest tam zawsze oddany dokładnie tak, jak na egzemplarzu kolońskim. Por. KDW, t. I, nr 393; KDW, t. VI, nr 27.

${ }^{55} \mathrm{KDW}, \mathrm{t}$. I, nr 228.

56 J. Mitkowski, Kancelaria Kazimierza Konradowica księcia kujawsko-łęczyckiego (12321267), Wrocław 1968, rozdział poświęcony dyktatowi.

${ }^{57}$ Pomijam tu identyczną ortografię transumptów rzekomego dokumentu fundacyjnego.

${ }^{58} \mathrm{Na}$ dokumencie z 23 IV 1375 r. spotykamy zapis Psiano (sic) de Rzgowo (KDW, t. III, nr 1721). Por. dokument z 2 IX 1352 r. na którym świadkuje Ozyas de Rzgowo (KDW, t. III, nr 1313). 
jako Rzgów ${ }^{59}$. Jeszcze bardziej charakterystyczny wydaje się zapis Chocenia na obu przekazach rzekomego dokumentu fundacyjnego klasztoru w Lądzie: Gotschene na egzemplarzu kolońskim i na jego transumptach, Moszczewe bądź Moszewe w kopiariuszach. Już S. Trawkowski, przyjmując zresztą za prawie wszystkimi krótszą wersję rzekomego dokumentu fundacyjnego za wcześniejszą i dysponując jedynie jego edycją z Kodeksu Dyplomatycznego Wielkopolski, miał kłopoty ze zidentyfikowaniem Moszewe z Choceniem na Kujawach ${ }^{60}$. Mam jednak wątpliwości co do tej identyfikacji, przyjmując zapis dłuższej wersji rzekomego dokumentu fundacyjnego. Niemniej taka identyfikacja utrwaliła się już w naszej historiografii ${ }^{61}$. Za identyfikacją Gotschene z egzemplarza kolońskiego z Choceniem na Kujawach przemawia to, iż w najbliższym sąsiedztwie Chocenia spotykamy Kłobię, wieś, z którą Choceń zawsze występuje na dokumentach lędzkich, i to również tam, gdzie identyfikacja nie rodzi już większych problemów ${ }^{62}$, a także to, iż klasztor lędzki pobierał z obu tych wsi, jedynych posiadłości na Kujawach, dziesięciny ${ }^{63}$. Warto zaznaczyć, iż nazwa wsi Choceń w XIII w. oddawana jest jako Choten ${ }^{64}$, Hodzna ${ }^{65}$ oraz Hocene ${ }^{66}$. Jak widać, daleko tu do zapisu znanego z kopiariuszy. Trzeba odnotować jeszcze rzecz charakterystyczną, która mogłaby wyjaśnić powód oddania w tak zniekształcony sposób Chocenia w kopiariuszach lędzkich - mianowicie zniekształcenie to staje się zrozumiałe dopiero, gdy spojrzy się na losy Chocenia w rękach cystersów lędzkich, a ściślej na moment, kiedy cystersi się go pozbyli. Nastąpiło to 20 VIII 1293 r., gdy mnisi lędzcy dokonali zamiany z księciem kujawsko-łęczyckim Władysławem Łokietkiem, oddając Kłobię i Choceń w zamian za Niewodniki i Cięślin ${ }^{67}$. Mając na uwadze to, że wszystkie pozostałe nazwy są oddane w kopiariuszach w formach sobie współczesnych, a więc w którymś momencie przerobionych, a część z nich nie odpowiada ortografii epoki, z której

${ }^{59}$ Zob. hasła w: F. Sulimierski, B. Chlebowski, W. Walewski (red.), Stownik geograficzny..., t. 10, s. 166-167; S. Kozierowski, Badanie nazw topograficznych..., s. 270. Do analogicznych wniosków dochodzi S. Rospond, który widzi zniemczenie nazwy przez dodanie nagłosowego i. Zob. S. Rospond, Stownik etymologiczny miast $i$ gmin PRL, Wrocław-Warszawa-Kraków-GdańskŁódź 1984, s. 339.

${ }^{60}$ S. Trawkowski, Gospodarka wielkiej własności cysterskiej..., s. 138.

${ }^{61}$ Z. Guldon, J. Powierski, Podziały administracyjne Kujaw i ziemi dobrzyńskiej w XIII-XIV w., Warszawa-Poznań 1974, s. 128; A.M. Wyrwa, Procesy fundacyjne..., s. 118.

${ }^{62} \mathrm{Na}$ przykład na dokumentach KDW, t. I, nr 298, 604 (405a); t. II, nr 707.

${ }^{63}$ Tak na dokumencie z 28 IV 1263 r., KDW, t. I, nr 604 (405a), który został uznany przez wydawcę KDW za falsyfikat.

${ }^{64}$ Ibidem.

${ }^{65} \mathrm{Na}$ autentycznym dokumencie z 26 IV 1283 r., KDW t. I, nr 522, wymagającym jedynie emendacji daty. Zob. B. Ulanowski, Dokumenty kujawskie i mazowieckie przeważnie z XIII wieku, „Archiwum Komisji Historycznej” 1888, t. 4.

${ }^{66}$ Tak na dokumencie z 20 VIII 1293 r., KDW, t. II, nr 707.

${ }^{67} \mathrm{KDW}, \mathrm{t}$. II, nr 707. 
rzekomo tekst przekazany w kopiariuszach klasztornych pochodzi, oraz uwzględniajc to, że zdecydowana większość wsi wymienionych w rzekomym dokumencie fundacyjnym w XVII-XVIII w., czyli w czasie sporządzenia kopiariuszy lędzkich, pozostawała nadal w rękach klasztornych bądź znajdowała się w najbliższej okolicy klasztoru, to staje się jasne, że kopista, dokonując odpisu, albo nie znał lub nie pamiętał o takiej posiadłości opactwa lędzkiego, albo dysponował mało czytelnym źródłem dla swojej kopii.

Rekapitulując dotychczasowe wywody, można stwierdzić, że z dwóch różnych przekazów dwóch wersji rzekomego dokumentu fundacyjnego wynika, iż to dłuższa wersja (egzemplarz koloński) ma bardziej archaiczną pisownię, odpowiadającą zarówno epoce, w jakiej ją sporządzono, jak i epoce, z której miałby pochodzić. Z kolei egzemplarz włocławski, przekazany dzięki kopiariuszom klasztornym, zawiera większość lekcji nie tylko oddanych w sposób późniejszy, już spolszczony, to jeszcze jest w nim sporo błędów, i to zarówno w pisowni nazw miejscowych, jak i osobowych. Co więcej, przekaz egzemplarza włocławskiego oprócz błędnie oddanych poszczególnych lekcji zawiera dwa oczywiste błędy ${ }^{68}$. Nie wiadomo jednak, co było podstawą nowożytnych kopii. Dokładną filiację wszystkich przekazów prześledził już T. Jurek ${ }^{69}$. Mając więc przygotowany grunt po rozpatrzeniu ortografii obu wersji dokumentu, co w swoich wywodach pominął T. Jurek, przyjrzę się teraz filiacji zaproponowanej przez tego uczonego i ukażę różnice w pewnych punktach.

Jak już wcześniej wspomniano, egzemplarz włocławski rzekomego dokumentu fundacyjnego klasztoru w Lądzie zachował się w dwóch kopiariuszach oraz dwóch odpisach. Najwcześniejszą kopię zawiera kopiariusz włocławski sporządzony w 1639 r. Jednak odpis egzemplarza krótszej wersji dokumentu fundacyjnego nie należy do zasadniczej części kopiariusza, lecz został sporządzony na osobnej karcie, a następnie wszyty na początku księgi. O późniejszym czasie sporządzenia tego odpisu świadczy również strona paleograficzna. Pismo odpisu krótszej wersji rzekomego dokumentu fundacyjnego jest późniejsze niż pismo zasadniczej części kopiariusza. Tę pierwotną kopię skolacjonowano z podstawą odpisu, mianowicie pierwotny zapis Rzgowo cum stabulario poprawiono na właściwe Rzgowo cum stabulariis et camerariis. Poprawki tej miano dokonać według T. Jurka po 1649 r., ponieważ następna kopia dokonana przez Stefana Damalewicza właśnie w 1649 r. posiada wciąż błędny zapis Rzgowa. Przy czym - jak słusznie zauważył T. Jurek odpis S. Damalewicza nie mógł być podstawą odpisu znanego z kopiariusza włocławskiego, gdyż nie dość, że pomija inwokację i arengę dokumentu, to zawiera

${ }^{68}$ Nie wiadomo jednak, ile błędów zawierała podstawa wszystkich nowożytnych kopii. Zob. poniżej uwagi odnoszące się transmisji tekstu krótszej wersji rzekomego dokumentu fundacyjnego klasztoru w Lądzie.

${ }^{69}$ T. Jurek, Dokumenty fundacyjne..., s. 9-11. 
pewne własne błędy: liczbę snopków żyta dostarczanych przez mieszkańców pierwszej grupy wsi klasztornych pomniejsza do IX, podczas gdy wszystkie inne odpisy podają zgodnie LX, co T. Jurek tłumaczy trudnością w odczytaniu tekstu kopiariusza, który jest w tym miejscu bardzo niewyraźny, oraz podając liczbę epakt za godzinę fundacji. Kolejnym odpisem, jakim dysponujemy, jest wyciąg z krótszej wersji rzekomego dokumentu fundacyjnego klasztoru w Lądzie, wykonany przez księdza Kazimierza Jarmundowicza w 1745 r., o tyle istotny, iż podaje on źródło swego odpisu, a którym miały być litterae erectionis eiusdem conventus per dictum Miecislaum anno 1145 mense Aprilis factae, które in archivo eiusdem conventus asservantur. Jednak odpis K. Jarmundowicza opiera się wyłącznie na pracy S. Damalewicza. Nie ma zatem pewności, chcąc ustalić źródło wszystkich nowożytnych odpisów, czy był to autentyczny dokument Mieszka III z połowy lat 90. XII w., a taką możliwość przyjmuje też T. Jurek, czy może nieznany nam dzisiaj kopiariusz klasztorny, czy wreszcie - mając na uwadze błędną kopię i zarazem wielce wymowną adnotację K. Jarmundowicza - jakiś luźny odpis na osobnej karcie papieru. Pamiętając o stronie ortograficznej obu przekazów, omówię pokrótce ostatni ze znanych odpisów krótszej wersji rzekomego dokumentu fundacyjnego klasztoru w Lądzie, znanego z kopiarusza klasztornego z 1795 r. ${ }^{70}$ Odpis ten oparty jest na wcześniejszym kopiariuszu lędzkim, o czym według T. Jurka świadczy nie tylko taka sama ortografia, ale także układ dokumentów w obu kopiariuszach ${ }^{71}$.

Z filiacji przekazów krótszej wersji rzekomego dokumentu fundacyjnego zaproponowanej przez T. Jurka wyłania się pionowy schemat stemma codicum. $\mathrm{Z}$ autentycznego dokumentu fundacyjnego dokonano wpierw odpisu na luźnej karcie papieru, którą dołączono do XVII-wiecznego kopiariusza klasztornego, a ten skolacjonowano z podstawą. Miało to nastąpić po 1649 r., czyli datą odpisu S. Damalewicza, o czym ma świadczyć błąd, jaki zawiera zarówno odpis tego autora, jak i pierwotny odpis. Następnie w 1745 r. K. Jarmundowicz dokonał odpisu wprost z dzieła S. Damalewicza, nie z autentycznego dokumentu fundacyjnego, który przez cały czas znajdował się w klasztorze lędzkim, o czym również świadczy protokół rewizji archiwum odnotowujący jego istnienie. Wreszcie w $1795 \mathrm{r}$. dokonano ostatniego odpisu do nowego kopiariusza klasztornego, któremu za podstawę posłużył XVII-wieczny kopiariusz. Natomiast dokument fundacyjny przepadł dopiero po kasacie klasztoru, która nastąpiła w 1819 r.

${ }^{70} \mathrm{KDW}$, t. I, nr 10.

${ }^{71} \mathrm{Z}$ przytoczonej przez T. Jurka wzmianki z protokołu rewizji archiwum polskiej prowincji cysterskiej z 1753 r., mówiącej o Fundatio monasterii Landensis per Mescho ducem Poloniae, datum anno 1145, który to dokument znajdował się in cistula $I V$, nie wynika, by klasztor lędzki w połowie XVIII w. posiadał autentyczny dokument fundacyjny Mieszka III, wszak K. Jarmundowicz osiem lat wcześniej również pisał o dokumencie fundacyjnym klasztoru sprzed 600 lat, ale przytaczał $\mathrm{z}$ niego błędne cytaty. 
Warto więc zastanowić się nad tym, co było źródłem wszystkich nowożytnych odpisów. Przypomnę tylko, że w rozważaniach nad ortografią obu wersji rzekomego dokumentu fundacyjnego klasztoru w Lądzie tekst przekazany przez kopiariusze klasztorne traktowałem osobno, a wnioski wysnute $\mathrm{z}$ analizy jedynie przez nie oddanych lekcji odnosiłem do tekstu archetypu egzemplarza włocławskiego. Z kolei T. Jurek, zestawiając poszczególne lekcje obu wersji rzekomego dokumentu fundacyjnego klasztoru w Lądzie, nie zagłębiał się w ich ortografię, choć zdawał sobie sprawę, iż w krótszej wersji dokumentu jest wiele błędów. Filiacja przekazów zawierających kopie krótszej wersji rzekomego dokumentu fundacyjnego zaproponowana przez T. Jurka, a streszczona powyżej, w kilku miejscach jest niezbyt mocno ugruntowana. Przede wszystkim niepewne wydaje się ustalenie chronologii najwcześniejszych odpisów. Taki sam błąd S. Damalewicza i pierwotnego odpisu kopiariusza włocławskiego nie może jednak świadczyć o wzajemnej zależności obu kopii. Fakt, że S. Damalewicz pomylił liczbę snopków żyta oddawanych przez mieszkańców klasztoru lędzkiego, a oddany w sposób mało czytelny w kopiariuszu włocławskim chyba też nie przesądza sprawy, ponieważ nie znamy źródła obu odpisów. Liczne pomyłki w najwcześniejszych przekazach, a przy tym wiele wspólnych błędów dla wszystkich nowożytnych odpisów mogą sugerować, że podstawa wszystkich kopii też mogła być mało czytelna, oraz sprawiają, że prawdopodobna wydaje się możliwość, iż dokonano kilku odpisów ze wspólnej podstawy, a nie - jak chce T. Jurek, kreśląc pionową zależność wszystkich kopii krótszej wersji rzekomego dokumentu fundacyjnego - kopiowano każdy następny odpis z wcześniejszej kopii. Charakterystyczne jest bowiem to, w jak zniekształcony sposób oddano we wszystkich przekazach krótszej wersji rzekomego dokumentu fundacyjnego zapis Chocenia. Przypomnę, iż z wcześniejszego rozbioru pisowni zarówno nazw osobowych, jak i miejscowych jasno wynikało, że to egzemplarz koloński zawiera poprawnie lub bardziej archaicznie wystylizowane lekcje zarówno nazw osobowych, jak i miejscowych, natomiast egzemplarz włocławski we wszystkich swoich przekazach oddaje je w sposób już spolszczony, a w każdym razie późniejszy niż na egzemplarzu kolońskim, bądź w sposób błędny. Nasuwa się jednak pytanie: Czy może, dokonując najwcześniejszego odpisu, nie zmieniono całej ortografii dokumentu, dostosowując ją do ówczesnych form? Trudno oczywiście na nie jednoznacznie odpowiedzieć, ale przypomnę, że wszystkie odpisy zawierają takie same błędne lekcje, przy czym bezpośrednią zależność kopii $\mathrm{T}$. Jurek zdołał moim zdaniem ustalić jedynie dla obu kopiariuszy lędzkich. Natomiast zależność S. Damalewicza od pierwotnego odpisu z kopiariusza włocławskiego oparta jest jedynie na wspólnym błędzie - obie kopie oddają jednakowo Rzgowo cum stabulario. Również fakt kolacjonowania pierwotnego, jak chce T. Jurek, tekstu odpisu krótszej wersji dokumentu nie jest pozbawiony swojej wymowy, choć być może to nie nieuważny kopista dokonywał 
poprawek ortografii dokumentu, ale raczej błędne lekcje musiały znajdować się już w podstawie odpisu.

Mając jednak na uwadze to, że wszystkie kopie krótszej wersji rzekomego dokumentu fundacyjnego cechuje nie tylko gorsza ortografia niż jakoby późniejszy egzemplarz koloński, ale i wszystkie zawierają wiele oczywistych błędów, a jednocześnie pamiętając, że zależność pomiędzy wszystkimi odpisami egzemplarza włocławskiego, układającego się stemma codicum, nie musi być pionowa, przyjmuję, że źródłem wszystkich nowożytnych kopii był jakiś wcześniejszy odpis. Możliwości takiej nie wykluczał też T. Jurek, wskazując oprócz XII-wiecznego autentyku również wcześniejszy kopiariusz klasztorny bądź luźną kartę papieru, luźny odpis. Odrzucając możliwość, iż to autentyk Mieszka III służył za podstawę wszystkich nowożytnych odpisów, zauważmy - mając w pamięci to, że K. Jarmundowicz, dokonując własnego odpisu, uważał, iż korzysta z autentycznego dokumentu fundacyjnego klasztoru w Lądzie i przytaczał jedynie tekst S. Damalewicza - że istnienie w klasztorze lędzkim osobnego odpisu, na osobnej karcie staje się bardziej prawdopodobne ${ }^{72}$.

Warto wyjaśnić, że starałem się dotąd wykazać, iż lepszy tekst, oczywiście w partiach wspólnych obu wersjom rzekomego dokumentu fundacyjnego, zawiera egzemplarz koloński. W związku z tym wszystkie próby rekonstrukcji pierwotnego majątku klasztornego bądź pierwotnych powinności mieszkańców wsi klasztornych, oparte na krótszej wersji rzekomego dokumentu klasztoru w Lądzie, cechuje dowolność ${ }^{73}$. Liczba dostarczanych wozów drewna i siana w instruktarzu powinności i obowiązków mieszkańców wsi klasztornych pierwszej grupy, jak również brak ostatniej z wsi klasztornych drugiej grupy, Świniarzewa, może świadczyć zarówno o narastaniu obciążeń poddanych klasztoru i powiększaniu jego majątku, jak i o prostym błędzie nowożytnego kopisty, takim jak opuszczenie kuchar przy Szetlewie, komorników przy Grabienicach, czy omyłek w ortografii.

Wciąż jednak nie wiem, co było podstawą przyjętego przeze mnie powyżej, obecnie zaginionego, odpisu, który stał się potem źródłem wszystkich nowożytnych kopii. Nie podejmując się na razie odpowiedzi na to pytanie, odnotuję, iż T. Jurek zdecydowanie odrzucił możliwość, by to drugi obecnie znany egzemplarz rzekomego dokumentu fundacyjnego był podstawą odpisu egzemplarza, określanego dziś mianem egzemplarza włocławskiego. Dla T. Jurka sprawę przesądzał fakt, że egzemplarz włocławski zawiera wszystkie formuły dyplomatyczne obecne i w dłuższej wersji, choć wydawało mu się niemożliwe opuszczenie tak obszer-

\footnotetext{
${ }^{72}$ Por. przypuszczenia T. Gintera, Działalność fundacyjna księcia..., s. 123-124.

${ }^{73}$ Por. S. Trawkowski, Gospodarka wielkiej własności cysterskiej..., s. 113.
} 
nej części dokumentu ${ }^{74}$ przez świadomego wagi swej pracy kopistę ${ }^{75}$. Zaznaczę również, iż Z. Kozłowska-Budkowa, omawiając obie wersje rzekomego dokumentu fundacyjnego, uznała krótszą wersję za wcześniejszą oraz zauważyła, że jej dopełnienie mógł stanowić falsyfikat rzekomo z $1181 \mathrm{r}^{76}$, zawierający klauzule zwolnień immunitetowych, które właśnie opuszcza egzemplarz włocławski ${ }^{77}$. Problem w tym, iż falsyfikat rzekomo z 1181 r. mógł na dobrą sprawę dwa razy w ciągu dziejów stanowić pewne uzupełnienie omawianego aktu, bowiem będąc oczywistym średniowiecznym fałszerstwem, posłużył mnichom lędzkim dwukrotnie. O pierwszym użytku świadczy data jego sfałszowania ${ }^{78}$, co do drugiego dowodnie potwierdzono go w 1546 r., w poznańskich księgach inskrypcji, skąd zresztą w ogóle go znamy. Pamiętając, iż słynne wyjście mnichów niemieckich z Lądu miało miejsce w 1553 r. i że wywieziono wówczas do Kolonii większość najważniejszych dokumentów klasztornych, a jednocześnie mając na uwadze wcześniejsze ustalenia co do źródła wszystkich nowożytnych odpisów, można stwierdzić, że sprawa autentyczności egzemplarza włocławskiego oraz wzajemnej relacji obu wersji rzekomego dokumentu fundacyjnego klasztoru cystersów w Lądzie odżywa z nową siłą. Niewykluczona staje się wszak możliwość dokonania odpisu w momencie opuszczenia klasztoru przez niemieckich mnichów. Zrozumiała oczywiście jest chęć posiadania przez pozostały w Polsce konwent dokumentu o zasadniczej wadze dla klasztoru. W takim wypadku odpisu dokonano by z pewnością właśnie z egzemplarza kolońskiego, jedynego przechowywanego w klasztorze, o stosunku mnichów do którego dowiadujemy się z napisu dorsalnego oraz nagłówka, pod jakim skopiowano go do głównego klasztornego kopiariusza. Na postawienie tej hipotezy pozwala fakt potwierdzenia na osiem lat przed opuszczeniem klasztoru w Lądzie przez część mnichów falsyfikatu rzekomo z 1181 r. zawierającego istotną część opuszczonego tekstu.

\section{DISCUSSION PERTAINING TO THE MESSAGE CONTAINED WITHIN THE FOUNDING DOCUMENT OF AN ABBEY OF THE ORDER OF CISTERCIANS IN LĄD}

\section{Abstract}

The following paper is devoted to the message contained within the founding document of the abbey of the Order of Cistercians in Ląd. This document has been preserved in several

${ }^{74}$ Zob. uwagi na początku artykułu o wzajemnej relacji obu wersji rzekomego dokumentu fundacyjnego klasztoru cystersów w Lądzie.

75 T. Jurek, Dokumenty fundacyjne..., s. 11.

${ }^{76} \mathrm{KDW}, \mathrm{t}$. I, nr 26.

77 Z. Kozłowska-Budkowa, Repertorium polskich dokumentów..., s. 43.

${ }^{78}$ Ibidem, s. 101. 
different versions. They vary not only in the message contained within (the alleged original and copies) but also in their contents as well as orthography. Recent research has assumed that the oldest and probably authentic document is the so-called "egzemplarz włocławski" [Włocławek copy]. It is the poorest one content-wise. However, an analysis of the spelling of proper names as well as of place names indicates that it could not have been created in this form in the $12^{\text {th }}$ century. Moreover, an analysis of the transmissions of all the known contents of the founding document of the abbey in Ląd leads to similar conclusions.

Keywords: abbey in Ląd, Cistercians, founding documents, forgery, document's message, critique of the text 